\title{
Çevreye Minberden Bakmak: Cuma Hutbelerinde Çevre Sorununun Sunumu
}

\author{
Metin Demir*
}

Öz: Cuma hutbeleri genelde akademik ilgiden mahrum kalmış ve fakat incelenmeyi hak eden bir konudur. Bir kitle iletişim vasıtası olarak Cuma hutbeleri hem sosyolojik hem de politik bir öneme sahiptir. Bu makalede, Cuma hutbeleri Althusser'in "ideoloji" kavramı üzerinden ele alınmıştır. Cuma hutbeleri ideolojik devlet aygıtlarından biri olarak kabul edilebileceği öne sürülmüştür. Araştırmanın konusu Cuma hutbelerinde çevre sorununun sunumudur. İdeolojinin operasyonu, en açık olduğu milliyetçilik, Kemalizm gibi alanlardan ziyade, kendini gizlediği tali bir alanda, yani çevre sorunu bağlamında ele alındı. 2001-2011 tarihleri arasında İstanbul Müftülüğü tarafından yayınlanan hutbelerin söylemi analiz edildiğinde, hutbelerin söyleminin belirli bir tarihten sonra keskin bir şekilde değiştiği gözlenmiştir. Önceleri insan merkezci, sığ bir çevrecilik anlayışı sergileyen hutbeler, daha sonra daha doğa-merkezci bir söyleme doğru evrilmiştir. Bu değişim süreci üzerinden din-devlet-ekoloji ilişkisi incelenmiştir. Görülüyor ki, Diyanet İşleri Başkanlığı (DiB), radikal İslam, cumhuriyet idealleri ve geleneksel İslami anlayışlar arasında tekinsiz bir konumda varlığını sürdürmeye çalışmakta ve çevre konusu üzerinden kendine bir yaşam alanı açmakta, din ve devlet arasında ılımlı bir zeminde faaliyet göstermeye gayret etmektedir.

Anahtar Kelimeler: Hutbe, Diyanet, ideoloji, Althusser, Çevrecilik, Doğa-Merkezci Çevrecilik, İnsan-Merkezci Çevrecilik.

\begin{abstract}
Friday sermons (khuțbah)are generally deprived of academic concerns and this situation deserves due investigation since, as a mass medium, they have a sociological and political importance. In this article, sermons are handled through Althusser's notion of "ideology." It is asserted that Friday sermons may be considered as one of the state's ideological apparatuses. The subject of research is an issue of the presentation and use of environment in sermons. The aim for chosing this subject, rather than other major topics such as nationalism, Kemalism et cetera, is to look at a secondary area because ideology displays itself in such kinds of hidden domains. If the sermons published by the Istanbul Müftülüğü in between 2001 and 2011 are analyzed, it will be seen that the discourse used in sermons dramatically changed after a certain date. Whereas earlier sermons represented a swallow, anthropocentric view, later a gradual evolution toward a more eco-centric view is observed. There is a visible tension between religion, the state and ecology which is observed through this process of change. It can be seen that Diyanet (The Presidency of Religious Affairs) seeks to maintain its existence in an uncanny situation between radical Islam, the Turkish Republic's ideals and traditional Islamic understandings; all while at the same time opening and securing itself a living space through the discussion of ecological issues.
\end{abstract}

Keywords: Friday Sermons (khuțbah), Diyanet, Ideology, Althusser, Environmentalism, Anthropocentric Environmentalist, Eco-Centric Environmentalism.

\footnotetext{
Yüksek Lisans Öğrencisi, İstanbul Şehir Üniversitesi Kültürel Çalışmalar Bölümü Iletişim: vmetindemir@gmail.com

Atıf(: Demir, M. (2012). Çevreye minberden bakmak: Cuma hutbelerinde çevre sorununun sunumu. Insan ve Toplum, 2 (3), 5-32.
} 
Her zaman camide toplanan halka oradan sesimizi duyurmak; oraları modern halkevleri haline koymak; din sınıfını ortadan kaldırmak, herkesi din ve dünya namına konuşturmak mümkündür. İslamlık bu bakımdan en modern, en ileri bir dindir.

\section{Ahmet Hamdi Başer}

Diyanet İşleri Başkanlığı eski danışmanı, emekli Kurmay Albay Oğuz Kalelioğlu'nun yönetiminde 2003 yılında yapılan araştırmaya göre, Türkiye'de 12 milyonu genç (1525 yaş arası) olmak üzere 23 milyon kişinin cuma namazı kıldığı tespit edilmiştir (Acar, 2003). Cuma namazı, sık tekrarlanan kitlesel bir eylemdir ve namazın içerisinde irat edilen Cuma hutbesi, bu ibadete politik bir hüviyet kazandırmaktadır.

Fakat ilginçtir ki bu denli sosyo-politik bir edim, akademik anlamda yeterince incelenmemiş, üzerinde yeterince düşünülmemiştir. Hutbelerin; sosyolojik, politik, ekonomik, psikolojik, eğitsel ve iletişimsel yönleri, birçok sebepten ötürü ayrı ayrı incelenmeyi gerektirmektedir.

Öncelikle, Cuma hutbesi şekilsel olarak "hatip tarafından irat edilen mev'ıza ve hitabedir" (Baktır, 1998, s. 425). Cuma ve Bayram namazları ile yağmur ve kusüf (güneş tutulması) dolayısı ile dört zamanda okunan, cami ve musallarda hutbe iradı için özel olarak hazırlanmış "minber" adlı yüksek bir yerden hatibin cemaate seslendiği bir dini iletişim şeklidir (Çakan, 1975, s. 26-27). Bu manada hutbe, bir kitle iletişim şeklidir. Fakat, yirmi birinci yüzyılda kitle iletişimin hayatın tüm alanlarına yayıldığı ve baş döndürücü bir hızla geliştiği, internetin ve sosyal medyanın hızla ilerlediği, ulusal sınırları aşarak dünyaya şekil verdiği, televizyon ve radyonun kitle üzerinde etkisinin herkesçe malum olduğu, hatta "kitle iletişim çağı" olarak tabir edilen bir dönemde, Cuma hutbelerinin varlığını sürdürmesi ilginç bir meseledir. En eski, en basit kitlesel iletişim formu olan yüksek bir yere çıkıp kalabalığa konuşma, bugün tüm bu teknolojilerin ortasında, bir ibadetin içerisinde mevcudiyetini devam ettirmektedir. Hatta hutbe, neredeyse hiçbir televizyon veya radyo programının başaramayacağı, her hafta düzenli olarak yaklaşık 20 milyon insana doğrudan ulaşma şansına sahiptir. Kitle iletişimin ekonomik-politik gücünün ziyadesiyle farkında olduğumuz bir çağda, hutbelerin bu kitlesel ehemmiyeti göz ardı edilemez. Aynı zamanda tekniğin durmak bilmez gelişmesine karşın, bu arkaik formun hâlâ bu kadar yüksek gücünün olması da üzerinde düşünülmesi gereken bir mevzudur. Öncelikle, hutbenin Cuma ve bayram namazlarının bir rüknü olmasının, "sözlü kültür"le yakın bir ilintisi vardır. Hem yüz yüze canlı bir iletişim aracı olması, hem de teknik imkânların şartları dolayısıyla kadim dönemden bu yana hutbe, mesaj iletme işlevini sürdürmektedir. Bu anlamıyla hutbenin, işitimsel ve konuşmaya dayalı kültürlerin hâkim olduğu ülkelerde iletişimin vazgeçilmez bir aracı olmaya devam etmesi, sadece ibadet yönü ile açılanamaz. "Araç mesajdır." iddiası bağlamında, araçtan 
ziyade "mesajın kendisi" olan hutbenin ilgi görmesinin ardında, hitabetin kadim bir olgu olması, halkın yazılı kültür pratiklerine hâlâ uzak olması ve dahası, sözü söyleyenin mevcudiyetinin hitap edilen kitle tarafından ontolojik güvenlik sağlaması gibi bir takım tarihsel-felsefi argümanlar öne sürülebilir. Hutbelerde mevcudiyet metafiziğine olan güveninin (ki ileri de göreceğimiz üzere ideolojik bir güvendir) gerçekliğini ve pratiğini görmüş oluyoruz. Hutbeler, mevcudiyet metafiziğinin en yaygın ve en somut örneklerinden birini teşkil etmektedir. Bir başka ifade ile sözün (nutuk, logos) gücünü arkasına alan hatip, kendi mevcudiyetini de hutbe pratiğine ekleyerek sözün daima yazıya nazaran üstün ve öncelikli olduğu düşüncesini fiilî olarak göstermektedir. Logosentrik gelenekten gelen sözün kutsallığı, hutbeye olan gizli ilgi ve güvenin örtük nedeni olarak değerlendirebiliriz.

Ayrıca hutbelerin pedagojik yönü de ilgiye değerdir ve bu konu, akademik anlamda görece daha çok çalışılmıştır. ' Hutbelerin psiko-sosyal etkisine dair çalışmalar ise yeterince yapılmamış, hutbelerin sosyolojik etkisi, dinleyiciler üzerindeki nüfuzu, alımlayan kitlenin hutbelere yaklaşımı ${ }^{2}$ ve sair konular yeterince incelenmemiş, konu ile ilgili saha çalışmaları pek yapılmamıştır.

Fakat burada özellikle üzerinde durulacak mesele, hutbelerin politik yönüdür. Minber, tarih boyunca iktidarın kendini ortaya koyduğu yahut gücünü gösterdiği bir siyasi meşruiyet alanı olagelmiştir. Ayrıca hutbe, fethedilen topraklarda İslam'ın siyasal hâkimiyetini ilan etmenin de bir yolu olmuştur. Mesela, Hanefi âlimleri, savaş yoluyla fethedilen ülkelerde İslam'ın gücüne imada bulunmak üzere kılıca dayanılarak hutbe okunmasını uygun görmüşlerdir (Baktır, 1998, s. 425).

Hz. Muhammed'in zamanında ve sonrasında hutbe, dinî fonksiyonun yanı sıra siyasi hâkimiyetinde sembolü olarak önem kazanmıştır. Hz. Ebu Bekir, halife seçildiği zaman takip edeceği siyasetin temel prensiplerini açıklayıcı mahiyette veciz bir hitabede bulunmuş, diğer üç Raşit halife de bu geleneği sürdürmüştür. Valiler de göreve başladıklarında benzer konuşmalar yaparlardı. İbn-i Haldun'un kaydettiğine göre, halife adına ilk hutbe okuyan kişi $\mathrm{Hz}$ Ali'nin Basra valisi Abdullah bin Abbas'tır. Hz Ali ile Muaviye arasındaki politik gerilimde İbn-i Abbas, Hz. Ali'nin adını hilafetin bir alameti olarak hutbede okumuş, halkında sükût ederek dinlemesini kendisine bir biat olarak kabul etmiştir. Abbasi halifeliği boyunca da halife adının anılarak kendisine dua edilmesi, hilafetin sembolü sayılmıştır. Bir kamusal güvenoyu mahiyeti taşıyan hutbenin ikinci kısmında halifenin isim ve lakabı zikredilerek dua edilir, zaman zaman da halife ve sultanlar övgü dolu uzun lakap ve vasıflarla anılırdı. Devletlerin meşruiyetinin temel şartlarından biri, hükümdarın kendi ülkesinde halife adına hutbe okutmasıydı. İslam

1 Konu ile ilgili tezler: (Döner, 2004; Suna, 1996).

2 Bu konuda Stuart Hall'un Reception Theory'sini (Alımlama Teorisi) teorik bir yaklaşım olarak kabul eden bir saha çalışması yapılabilir. 
tarihinde kadın hükümdar ve yöneticilerin de erkek yöneticiler gibi kendi adlarına hutbe okuttukları bilinmektedir. Hutbe, halife ile sultan veya eyalet valileri ve mahalli hanedanlar arasında güç dengesinin sembolik bir işaretiydi. Osmanlı döneminde de sultanlar ve bazı yerel beyler adına hutbe okunmuştur. Hatta 1876 Anayasası'nın 7. Maddesi'nde, padişah adına hutbe okunması, onun hâkimiyet hakları arasında sayılmıştır (Baktır, 1998, s. 426).

Görüldüğü üzere hutbeler, İslam tarihi boyunca birçok dinî ve toplumsal işlevinin yanında, politik bir konu olarak da telakki edilmiş, iktidarın bir operasyon alanı olarak görülmüştür. Cumhuriyet döneminde de hutbeler üzerinden devrimler halka aşılanmaya devam edilmiştir. Örneğin, cumhuriyetin faziletleri anlatılmış, askerlik (Akseki, 1937, s. 200) ve militarizm övülmüş, (Usta, 2005, s. 225) vatan sevgisi, (Akseki, s. 307) vatana bağlılık (Diyanet İşleri Başkanlığı, 1981, s. 497) ve vatan uğrunda fedakârlık (Vahid, 1928, s. 29) gibi konular etrafında millî kimlik oluşturma (Diyanet İşleri Başkanlığı, s. 485) gayretleri sürdürülmüştür. Yeni kurulan cumhuriyet rejiminin halk tarafından benimsenmesi adına hutbeler verilmiş (İstanbul Müftülüğü, 2004c), genç cumhuriyetin kurucu kavramlarının inşası için sürekli bir şekilde kavramların (İstanbul Müftülüğü, 2003b) ehemmiyetine vurgu yapılarak resmî ideolojinin onayı alınmaya çalışılmış ve aynı zamanda halkın da resmî ideolojiye eklemlenmesine yardımcı olmuştur. Ayrıca, hutbeler vasıtasıyla kalkınma (İstanbul Müftülüğü, 2004d) ve çağdaşlaşma ülkülerine, bilimsel (Vahid, s. 138) ve teknolojik (Akseki, s. 7) gelişmelerin önemine dikkat çekilmiştir. Ekseriyetle, Türkiye'de "apolitik" konulardan bahseden cuma hutbeleri görüldüğü gibi zaman zaman da hutbeler doğrudan devlet söylemine eklemlenmiştir.

Bu çalışmada, cuma hutbelerinde "politik olmayan" bir konu ele alınacaktır. Cuma hutbelerinde ulusal kimlik, laiklik-dindarlık gerilimi, milliyetçilik gibi görece daha tartışmaya açık ve gündemde olan konular yerine, özellikle çevre konusuna eğiliyorum. Çünkü iktidar, tam da bu gözden kaçan, gizlenen, önemsizmiş gibi görünen alanlarda kendini gösterebilmektedir. Bu şekilde devletin bir kurumu olan Diyanet İşleri Başkanlığı́nın hutbeler aracılığıyla çevre sorunlarını nasıl kodladığını incelemek, iktidarın bu dar alanda nasıl çalıştığını görmeye vesile olacaktır.

Bu sebeple, bu çalışmada ilk önce teorik bir zemin olarak cuma hutbelerinin, "ideolojik Devlet Aygıtı" olarak ele alınıp alınamayacağını sorgulayacağım. Burada Althusser'in teorisini kullanmamızın nedeni, bu teorinin siyasal aygıta uzak gibi görünen birçok kurumun, burjuva ideolojisi bağlamında nasıl birbirine eklemlendiğini ve birbirlerini meşrulaştırdıklarını göstermesidir. Böylece öncelikle, Louis Althusser'in “ideolojik Devlet Aygıtları" adlı eserinde bahsettiği "ideoloji", "ideolojik aygıt" gibi kavramları kısaca açıklayarak Althusserci bir zaviyeden hutbelerin değerlendirilmesinin uygun olup olmadığını sorgulayacağım.

Ardından, çevreci hareketler ve çevreci yaklaşımlardan kısaca bahsederek 2001-2011 tarihleri arasında İstanbul Müftülüğü'nün yayınladığı resmî hutbeleri temel alarak 
DiB'in bu yaklaşımlardan hangisini benimsediğine, tavrının mevcut idari yapının tavrı ile olan ilişkisine göz atacağım. Yine bu şekilde tekrar Althusser'e dönerek DỉB ve devletin çevre konusundaki yaklaşımlarının benzerlik ve farklılıklarının ideolojik açıdan nasıl bir anlama geldiğini inceleyeceğim.

Son olarak, cuma hutbelerinde, çevre sorununun sunumu konusu üzerinden, dinekoloji- devlet ilişkine dair kavrayışlarda bulunmaya çalışarak Osmanlı'dan Cumhuriyete geçiş sürecinde neredeyse her yol ayrımında, her düğümün ilmeklerinde yeniden gündeme gelen din-devlet ilişkisini, Diyanet'in tekinsiz konumuna farklı bir zaviyeden bakarak Diyanet üzerinden yakın tarihimize bakmayı amaçlıyorum.

\section{Cuma Hutbeleri İdeolojik Devlet Aygıtı Olarak Ele Alınabilir mi?}

Bugün ideoloji üzerine olan literatür öyle hacimlidir ki ideoloji derken neyin kastedildiğini, hangi anlamda kullanıldığını belirtmek bir zorunluluk haline gelmiştir. Eagleton'ın (1996) İdeoloji adlı eserinde genel olarak saydığı üzere, ideoloji kavramı en az 10 farklı şekilde anlamak veya tanımlamak mümkündür (ki bazıları diğerleri ile taban tabana zıttır). Bu tür bir anlam kargaşasından dolayı başta belirttiğimiz üzere, burada Althusser'in ideoloji kavramını ele alacağız.

Cezayir doğumlu Fransız filozof Louis Althusser, farklı türden bir Marx okumasıyla, yapısalcı Marxizm ile post-yapısalcı kuramsal ve siyasal Marxizm varyantları arasında köprü görevi görmüştür (Muck, 2003, s. 183). Öğrencileri arasında M. Foucault, P. Bourdieu, J. Derrida gibi ünlü isimler olan Althusser, ideoloji kavramı üzerinden Marx'ı yeniden okumaya girişir. Bundan hareketle oluşturduğu bilim-ideoloji karşıtlığı kuramının çatısını oluşturmaktadır

Althusser; dünyayı, pratikler dünyası olarak görür. Marx'tan miras aldığı praksis felsefesi uyarınca dünya toplumsal pratik ve teorik pratikten oluşur. Teorik pratik alanı, bilimsel olan ve ideolojik olan diye ayırmaktadır. Ona göre, Marx'ta bilgi ve teorik çalışmalar, sadece zihni ilgilendiren, maddi varlığı olmayan olgular değil, aksine praksis'in bir parçasıdır. Althusser teorik, pratikten söz ederken bu biçimiyle bir materyalizme katıldığı savındadır. Althusser'e göre, reel nesne ile bilgi nesnesini ayıran Descartes idealizmine savaş açan Spinoza'dır. Bu yüzden Marx'ın gerçek fikir babası, Hegel'den ziyade Spinoza'dır (Tura, 1990, s. 27).

Althusser, döneminde yaygın bir moda olan Marxizm'in varoluşçu versiyonlarına, özgürlüğü ve özneyi öne çıkaran Marx okumalarına ve bu nedenle döneminde sıkça yapılan Marx'ın erken dönem eserlerine dönme eğilime karşı çıkmıştır. Ona göre, Marx'ın gençlik yazıları, döneminde sanıldığının aksine Marx'ın ana felsefesini yansıtamazdı; çünkü bunlar ideoloji yüklüydü ve bunlar ile Kapital'in yazarı olgun Marx arasında epistemolojik kopuş vardı. Althusser'e göre, Hegel ve Feuerbach'tan uzaklaşması 
Marx'ın epistemolojik kopuşuna vesile olmuş, böylece hümanizmin bilimsel gerçeği perdeleyen ideolojisinden kurtulmuştur.

Ona göre, Marxist (bilimsel) teoriye iki ideoloji bulaşmıştı ve bilimi bu ideolojik enfeksiyondan temizlemek gerekiyordu. Bunlar, hümanizm ve tarihselcilik ideolojileri idi. Kant ve Ficthe'den Husserl ve Sartre'a kadar tüm felsefeler, özne (sujet), özgürlük, bilinç, yabancılaşma gibi kavramları hümanist bir sistemin dayanağı yapmışlardı. Oysa Marx, "Analiz yönetimim insanlardan hareket etmiyor, belli bir dönemden hareket ediyor." diyordu ve teorisini "insan"dan değil, bir toplumsal formasyonu oluşturan üretim ilişkilerinden hareket ederek kurmuştu. Soyut insan ya da özne, ideolojik bir tasavvurdu, gerçek insan ise üretim ilişkilerinin dayanağı olarak ortaya çıkıyordu (Muck, 2003, s. 133).

Genç Marx, Hegel ve Feuerbach'ın yolundan gitmekteyken birden onlardan kendini koparmış ve hümanizmin yanıltıcı tasallutundan kurtulmuştur. Marx'ın ideolojiden bilime bu geçişi, Althusser'de hocası Gaston Bachelard'dan aldığı "epistemolojik kopuş" ve kendi tabiri olan "teorik sorunsal" kavramları ile açıklanmaktadır.

Althusser'e göre, genç Marx Feuerbach'çı yabancılaşma, Hegel'deki dünya tinine benzer bir şekilde insanlık kavramı üzerine düşünen bir yazarken olgun Marx; bilim, tarihsel materyalizm, toplumsal formasyonların teorisi ve tarihi, bunu yapısal açıklamasının kavramları, üretim ilişkileri ve güçleri, ekonomik belirlenim, üst-yapı, devlet ideoloji gibi konulara yoğunlaşmıştır. Marx, bundan sonra hümanist felsefeyi temellendiren felsefi antropolojiyi reddederek yerine üretim tarzı kavramına dayanan, bilimsel sorunsalı getirir. İki düşüncesi sistemi, "epistemolojik bir kopma" ile birbirinden ayrılmıştır (Tura, 1990, s. 32). Bu kopuntu, Marx'ın söyleminde söyledikleri ve söylemedikleriyle ve yapıtının altında yatan sorunsalı ortaya koyabilecek bir okumayla açığa çıkarılabileceği vurgulanır. Marx'ın bilimsel hale getirdiği ideoloji nedir ve nasıl işler? Althusser'in (2010) konudaki açıklamalarını şöyle toparlamak mümkündür:

1. İdeolojinin tarihi yoktur: (s. 179) Althusser'e göre, ideoloji kavramı, var olmuş tüm sosyal ve tarihsel içerikleri yapılandıran bir çerçeveye işaret eder. İdeoloji, bilinçdışı gibi sonsuzdur, yani sınıf mücadelesi sona erse bile hiç yok olmaz. İdeoloji, eğer insanlar biçimlenecekse, dönüştürülecek ve varlık koşullarını ihtiyaçlarına cevap vermek için mücehhez kılınacaksa, bir toplum için vazgeçilmez bir şeydir ve kaçınılmaz sosyal formasyondur (Lock, 1996, s. 75).

2. İdeoloji, bilinç düzeyinde, bireylerin gerçek varoluş koşullarıyla kurdukları imgesel ilişkinin imgesel bir tasarımlanmasıdır. İdeolojide tasarımlanan, bireylerin varoluşunu yöneten gerçek ilişkiler sistemi değil, bu bireylerin boyun eğerek yaşadıkları gerçek ilişkilerle kurdukları imgesel ilişkidir (Althusser, 2010, s. 92-93).

3. İdeoloji maddi bir varoluşa sahiptir. Althusser, (2010) ideolojiyi oluşturur gibi görünen "düşüncelerin" ya da tasarımlamaların ülküsel, düşünsel, tinsel, değil, maddi bir 
varoluşa sahip olduklarını iddia eder. Bir ideoloji, bir aygıtta ve bu aygıtın pratik ya da pratiklerinde var olur bu da hep maddi bir var oluştur. Tek bir öznenin inançlarını oluşturan düşünceler maddi anlamda vardır; şöyle ki, bu düşünceler maddi ideolojik aygıtlar tarafından tanımlanan maddi kurallarca belirlenen, maddi pratiklerde yer alan maddi edimlerdir (s. 93).

Maddi bir kurallar bütünü tarafından düzenlenen, maddi pratikler gerektiren, maddi bir ideolojik aygıtın bağrında var olan ideoloji; söz konusu pratiklerle, kendi inancı uyarınca eylediğine gönülden inanan bir öznenin maddi eylemlerinde var olur (s. 98).

4. İdeoloji, bireyleri özne olarak çağııır. Özne kategorisi, her tür ideolojinin kurucusudur; ama her tür ideoloji, somut özneler kurma işlevine sahiptir. Böylece ideoloji tarafından kurulmuş özne, aynı zamanda ideolojinin kurucusu olur. Her tür ideolojinin işleyişi de ancak bu çifte kuruluş içinde var olabilir (s. 99).

Althusser'e göre bireyler, zaten-hep birer öznedir ve ideolojik kabul etme kurallarını durmaksızın yerine getirirler. Kabul etme/tanıma ve kabul etmeme/tanımama (méconnassiance) süreçleri üzerinden ideoloji kendine özgü işlevleri yerine getirir. İşte bu kuralları yerine getirmemiz dolayısıyla bizim somut, bireysel, başkasıyla karıştırılamaz ve yeri tutulamaz özneler olmamız güvenceye alınır (s. 101).

Her türlü ideoloji, özne kategorisinin işleyiş̧i sayesinde, somut bireylere somut özneler olarak seslenir. Somut bireylerle somut özneler ayrıdır. İdeoloji, somut bireyleri öznelere dönüştürür, bunu da seslenme (interpellate) denilen son derece kesin bir işlem yoluyla gerçekleştirir. İdeolojiler, dur durak bilmeksizin özne diye seslenirler öznelere; zaten-hep özne olanları, bireyleri "istihdam" ederler durmadan.

Althusser (2010), seslenme kavramını din üzerinden şöyle açıklar: Dinsel ideolojinin özneye dönüştürmek için bireylere seslendiğini, onun çağrıya (buyruklara) uyup uymamakta özgür bir özne haline getirmek için Pierre'e seslendiğini göz önüne alırsak, zaten hep kişisel kimliğe sahip özneler, bu çağrıya "evet benim gerçekten" diye yanıt veriyorsa, onlara dünyadaki yerleri diye gösterdiği yeri kabul ettiriyorsa, yaşamı ya da ebedî laneti kabul ettiriyorsa ritüelleriyle; bu durumda sahneye Hristiyan dinine uygun özneler çıkartan bu prosedüre çok tuhaf bir olgunun egemen olduğunu belirtmemiz gerekir: dinsel öznelerin bu kadar çok sayıda var olabilmelerinin mutlak koşulu, Tek, Mutlak, bir Öteki Özne'nin, Tanrı'nın var olmasıdır. "Tanrı Musa'ya seslendi: Musa Benim (gerçekten)!" dedi, kulun Musa'yım, konuş ve seni dinleyeceğim!" ve Efendimiz Musa ile konuştu: “Ben, Ben olanım!” (s. 109).

Demek ki Tanrı Özne, Musa ve Tanrının halkını oluşturan sayısız özne de, Tanrının seslendiği konuştuğu kişilerdir. Bireylere, Mutlak ve Biricik Özne adına özne olarak seslenen her ideolojinin yapısını ayna nitelikli, yani yansımalı ve çifte yansımalı olduğunu görüyoruz. Her ideoloji bir merkeze sahip ve Mutlak Özne merkezdeki biricik yerde 
bulunur ve çifte yansımalı bir bağıntı içinde, öznelere, her öznenin kendi görüntüsünü şimdi ve gelecekte izleyebilecekleri Özne'de, sonsuz sayıda bireyin özne olarak çevresini alması için seslenmesi demektir. İdeolojinin çifte yansımalı yapısı aynı anda şunları sağlar:

1. Bireylere özne olarak seslenilmesi

2. (Mutlak) Özneye tabi olmaları

3. Özne ile öznelerin, kendi aralarında birbirlerini tanımaları ve öznenin kendi kendisini tanıması

4. Her şeyin yerli yerinde olduğuna ve öznelerin ne olduklarını tanıyıp kabul etmeleri ve buna uygun biçimde davranmaları koşuluyla her şeyin yolunda gideceği konusunda mutlak güvence (Althusser, 2010, s. 207).

Özneleştirme/ Tabi kılma (subjection), evrensel tanıma/ kabul etme ve mutlak güvenceden oluşan bu üçlü düzende sarılan özneler, "kendiliklerinden işlerler". Bu üç terimin merkezi, özneleştirme/tabi kılmadır. İdeoloji zaten-hep özne olan bireyleri, yani ben ve sizleri "işletir".

Her özne, aynı anda birden çok sayıda ideolojinin içinde ve etkisinde yaşar; bunlar bir araya gelir ve düzenlenir. Her üretici biriminin ya da elementin, birbirleri ile ilişki içinde bulunarak ve karmaşık yapılı bir bütüne dönüşecek şekilde hareket eden ve hiç biri bir diğerinin basit ya da özsel sebebi konumuna indirgenemeyeceği düşüncesine Althusser, "yapısal nedensellik" (structural causality) der. Ardından bu teori, aşırı-belirlenim (over-determination) ya da bir tarihsel moment oluşturan üretici proseslerin bütününde, her elementin diğer tüm elementler tarafından belirlendiği düşüncesi ile bağlıdır. Belirli bir periyotta belli, mücessem ve çok yönlü pratikler bir üretim biçiminin içinde yer alır. Bu özel pratikler içinde ve bunların arasında bir gerilim olabilir yahut olmayabilir. (contradiction) Hiyerarşik bir biçimde bütünleşmiş bu kesimlerin bir "merkez"i yoktur, son kertede belirleyici olan iktisat kesimi ise de bu farklı kesimlerin karşılıklı etkileşim ve belirleyicilik süreci içinde bir "yapı etkisi", daha özgül bir deyimle "aşırı belirleme" (surdétermination) ortaya çıkar. İdeoloji, yapının bir etkisi olarak ortaya çıkar. Daha kesin bir ifadeyle ideoloji; ekonomik, politik/hukuki ve ideolojik toplumsal düzeyler arasındaki ilişki ve çelişkilerin ortaya çıkardığı bir oluşumdur (Sancar, 2008, s. 53).

Her toplumsal yapı, var olmak için bir yandan üretirken bir yandan da üretim koşullarını yeniden üretmesi gerekir. Yani üretici güçler ve varolan üretim ilişkileri yeniden üretilmelidir. Bu da devlet aygıtları eliyle gerçekleşir. Bu yeniden üretim, Baskıcı Devlet Aygıtları ve İdeolojik Devlet Aygıtlarıyla garanti altına alınır. Ne zamanki üretim koşullarının yeniden üretimi gerekse, üretim ilişkilerinin yeniden üretimi kurulu düzendeki iş gücünün özneleştirilmesini içeren bir tür devreye girer, böyle bir özneleşme (subjectification) vuku bulur. 
Bizim anladığımız anlamda devlet, yani burjuva devleti, hükümetten başka bir şeydir der Althusser. Devletin elinde kendi siyasal ideolojik aygıtı (hükümet bu aygıtta yer alır) dışında daha başka ideolojik aygıtlar da vardır. Siyasal ideolojik aygıt, eninde sonunda başka bir sürü başka aygıttan (Kilise, Medya, Okul vs) biridir (Althusser, 2010, s. 17). Devletin siyasal aygıtını (devletin başı, hükümet, idare) siyasal devletin ideolojik aygıtlarından ayırmak gerekir. Devletin siyasal aygıtı baskı aygıtı, siyasal devletin ideolojik aygıtı ise İdeolojik Devlet Aygıtları arasında yer alır. Aygıtlar arasındaki ayrımı belirleyen şey, bir aygıtın baskıya mı yoksa rızaya mı dayandığıdır. Bu ayrım işlevseldir, devletin ideolojik aygıtları bile birçok durumda gizli ya da sembolik olarak şiddete ve baskıya yer verirler. Mesela okulda fiziksel cezalar verilebilir. Ya da baskı aygıtı hukuk, felsefi söylemlere dayanabilir.

Devletin tek bir baskı aygıtı; ama birçok ideolojik aygıtı vardır. Baskıcı olduğunu kesin bir şekilde söylediğimiz devlet aygıtı, kendini organik bir bütün olarak gösterir; daha kesin olarak söylersek doğrudan doğruya bilinçli olarak tek bir merkezden yönetilen ve merkezîleşmiş bir beden olarak gösterir kendini. Hükümetin hemen altında ya da hükümete bağlıdırlar. Devletin baskı aygıtlarının organik bir bütün olduğunu söyleyebiliriz. Devletin ideolojik aygıtlarında ise durum değişiktir. Bu aygıtlar çoğul olarak var olurlar ve görece bağımsız bir maddi varoluşa sahiptir. Aralarında kaçınılmaz geçişimler yaşansa bile D.I.A'lar birbirlerinden ayrı, görece özerktirler ve tek ve bilinçli bir yönetim altında merkezîleşmiş örgütlü bir beden oluşturmazlar (Althusser, 2010, s. 56). Birbirinden farklı ideolojik devlet aygıtlarının birliği ise bu aygıtların her birinin kendi alanında ve kendine özgü kiplikte, kendi içinde farklar, hatta çelişkiler olmasına rağmen, devlet ideolojisi olan bir ideolojiyi gerçekleştirmeleri ile sağlanmaktadır. Öyleyse devlet, baskıcı devlet aygıtları ile ideolojik devlet aygıtlarının, iktidarının altında bir araya gelmesidir. Althusser, kamusal alanla özel alanın sınırlarını çok fazla göz önüne almadan bir devlet portresi çizmiştir. Kendisi kamusal-özel ayrımının da burjuva hukukuna dayandığını, oysa devletin hukukun ötesinde olduğunu iddia eder. Fakat yine de devletin sınırlarını belirsizleştirdiği konusunda eleştirilir.

Devlet ideolojisi nedir? Althusser'e (2010) göre Devlet İdeolojisi, ideolojinin farklı bölgelerinden (dinsel, hukuki, ahlaki, siyasal) alınma belli sayıdaki ana izleği, devlet iktidarını elinde bulunduran sınıf egemenliğinin, yani üretim ilişkilerinin yeniden üretimini sağlamak için gerek duyduğu özsel değerleri özetleyen bir sistem içinde toparlar. Burjuva devleti söz konusu olduğunda devlet ideolojisi içinde toplanan özsel değerler şunlardır: milliyetçilik, liberalizm, ekonomizm ve hümanizm (s. 59).

İdeolojinin, üretim ilişkilerinin yeniden üretilmesinde önemli bir rolü vardır. Çünkü emek gücünün yeniden üretiminin asıl bölümü işletmenin dışında gerçekleşir (Althusser, 2010, s. 156). Bu da kapitalist eğitim kurumlarında, meslek edinirken, gereken görgü kurallarına tabi olurken, yurttaş olma bilinci, meslek ahlakı gibi toplumsal-teknik-işbölümüne saygılı davranırken kurulu düzenin kurallarına boyun 
eğmenin yeniden-üretilmesi gerçekleşir. Yani okul, kilise, ordu gibi kurumlar bir sürü beceri öğretiyor ama bunu egemen ideolojiye tabi olmayı sağlayacak biçimde yapıyor. Negri'nin dediği gibi, "ideolojik devlet aygıtları, canlı işin tekilliği ile soyut kapital ve devletin baskısını uzlaştırmıştır. Dünya, ideolojik aygıtlar aracılığıyla Kapitale dahil edilmiştir" (Negri, 1996, s. 57). Dinsel Di̇A, Öğrenimsel Di̇A, Aile DíA'sı, Hukuki DíA, Siyasal DIA (partiler sistemi) Sendikal DíA, Haberleşme DíA'sı ve Kültürel DíA...Tüm devlet aygıtları, hem ideoloji hem de baskı kullanarak işlerler. İdeolojik Devlet Aygıtları arasındaki birlik, egemen ideoloji tarafından, egemen sınıfın ideolojisi tarafından çoklukla çelişkili biçimlerde sağlanır.

Şu halde, Althusser'in dinsel aygıt olarak örnek verdiği kilise kurumunu nazar-ı itibara alırsak, Diyanet İşleri Başkanlığı'nı da ideolojik dinsel aygıt olarak düşünebiliriz. Böyle bir tutum, basit bir kopyacılık ya da bir tür oryantalizm olarak görülmemeli, aksine yeni bir bakış açısı sağlayacak teorik bir deney olarak telakki edilmelidir. Çünkü Althusser, bir din olarak Hıristiyanlığı değil, politik yönü de olan bir kurum olarak Kilise'yi kendine konu edinmiştir. Aynı şekilde burada da İslam dini ve onun çevre sorunu konusunda görüşü değil, politik ve sosyal önemi itibari ile bir devlet kurumu olan Diyanet İşleri ele alınacaktır. Bu nedenle bir metot olarak Althusserci düşünce tarzı, araştırma nesnemize uygun düşmektedir.

Cuma hutbesinde imam, öncelikle Mutlak Özne (Allah) adına, ardından devlet adına, bireylere "Muhterem Müslümanlar" diyerek seslenmekte, onları teolojik ve politik otorite karşısında tabi olmaya ve aynı zamanda ideolojinin çifte işleyişi prensibince, bireylerinde "Müslüman Özneler" olarak kendilerini tanımalarına ve güvence altına almalarına imkân tanımaktadır. Çoğunlukla; siyasal, hukuki, ekonomik, ailevi ideolojik aygıtlarla ve ideolojik baskı aygıtlarıyla eşgüdüm halinde olan dinsel aygıt, kimi zamanda onlarla çelişmekte, özerk otonomisini göstermektedir.

Dinsel ideoloji, cuma hutbelerinde maddi bir pratik halini almakta ve basit pratikler yoluyla (diz çökmek, sessizce dinlemek, yüksekteki hatibe bakmak vs.) işlemektedir. Hutbe okuyan hatip, hem literal anlamda hem de Althusserci anlamda zaten-hep özne olan bireylere, "Muhterem Müslümanlar" diyerek seslenmekte, Mutlak Özne ve Devlet adına cemaatin öznelerini, özne olarak yeniden konumlandırmaktadır. Ayrıca göreceğimiz üzere, burjuva devlet ideolojisinin neredeyse tüm özelliklerini, yani hümanizm, ekonomizm, milliyetçilik fikirlerine dayalı bir bilinç dışı oluşturmakta, emeğin ve üretim ilişkilerinin yeniden yaratılmasını çalışma sahası dışında üreterek, aşırı-belirlenimin bir öğesi olarak genelde ideolojik devletin okyanusuna katılmaktadır.

Tüm bunlar göz önüne alındığında, Althusserci anlamda DỉB kurumunu dinsel ideolojik aygıt ve hutbeleri bu aygıtın maddi bir pratiği olarak ele almanın mümkün olduğu kanısındayım. Bu aygıtın, çevre sorunu telakkisini incelemeye geçmeden önce, kısaca çevre sorunu ve farklı çevreci yaklaşımları izah etmek açıklayıcı olacaktır. 


\section{Çevrecilik ve Minberin Çevreciliği}

Çevreci hareket, tarihsel olarak üç aşamaya ayrılabilir: Birinci aşamayı bilimsel çevrecilik hareketi oluşturmaktadır. Biyolog Ernst Heackle'ın 1876 yılında ekoloji kelimesini kullanarak bir bilim yaratması ile başlayan süreç, doğal denge ve doğadaki canlıların korunması gereğinin idraki ile insanlık gündemine taşınmıştır. İkinci aşamada, çevreci hareketin 68 Olayları ile birlikte toplumsal bir hareket olarak ortaya çıkışı yer almaktadır. Son aşamada ise 1979 'dan itibaren siyasal bir oluşuma dönüşen Yeşiller Hareketi'nin başını çektiği çevreci hareket bulunmaktadır (Ceritli, 1998, s. 256).

Batıda çevreciliğin gelişimi sürecinde birçok fikir ayrılıkları oluşmuş ve farklı yaklaşımlar gelişmiştir. Bu farklı grupların temelinde, üç etik yaklaşım olduğunu görürüz.

\section{Doğa Merkezci Yaklaşım}

Doğanın kendi içinde haklara sahip olduğuna, insan kullanımından bağımsız olarak doğanın kendine ait hakları olduğuna ve insanın doğa içinde ayrıcalıklı bir konumu olmadığına inanan yaklaşımdır. Tek tek sorunlar yerine, belirtileri sorunsallaştırarak ele alan bu yaklaşımlara aslında köktenci yaklaşımlar da denebilir. Köktenci yaklaşımların siyasal bir takım tezahürleri vardır. Bunların en önemlilerinden biri olan ekososyalizm, küresel çevresel krizin kökeninde kapitalizmi görür ve kapitalizme karşı verilecek mücadelenin kirlenmeye karşı verilecek mücadeleyle bir olduğu görüşüne sahiptir. Ekososyalizm, bireylerin toprağın sahibi değil kiracısı olduğunu savunan ve almaşık üretim biçimlerinin, küçük işletmelerin, silahsızlanmanın desteklendiği bir akımdır Joel Kovel, Michael Löwy, Andre Gorz, Barry Commoner, Rudolp Bahro gibi tanınmış taraftarları vardır (Keleş, Hamamcı \& Çoban, 2006, s. 294).

Murray Boockhin'in temsilcisi olduğu eko-anarşizm felsefesi de yine köktenci anlayışta bir siyasal harekettir. İnsanlar üzerinde baskı kuran hiyerarşik yapılarla, doğa üzerinde baskı kuran yapıların aynı mekanizmalar olduğundan hareketle Bookchin, sınıfı toplumsal yapıların ve hiyerarşik düzenin sonu gelmeden ekolojik kurtuluşun da mümkün olmadığını savunur (Boockhin, 2010).

Vol Plumword, Maria Mies, Ariel Salleh gibi isimlerin savunduğu Eko-feminist akıma göre, kutsal anne olarak algılanan doğanın tarım toplumu tarafından kontrol edilmesi ile kadının dominasyonu simültane ortaya çıkar. Bu yaklaşımı benimseyenler, ekolojik sapma ve patriarkal baskı eş zamanlı ortaya çıktığı için kadınların üzerindeki baskının kaldırılması ile doğa üzerindeki tahribatın önlenmesi ortak bir strateji ile giderilebilir demektedirler (Salleh, 1997).

\section{Insan-Merkezci Yaklaşım}

Doğa merkezli bakışın karşısında yer alan insan merkezci yaklaşımın temel metafizik argümanı, doğanın insan için bir anlamı olduğu ve tüm doğanın insanlık için bir kaynak olduğu görüşüdür. Kaynakların akıllıca kullanılması, gelir dağılımının daha dengeli olması, alternatif enerji kaynakları ve sürdürülebilir kalkınma gibi çözüm önerileri 
üzerine yoğunlaşan insan merkezci yaklaşım, radikal bir hayat algısı değişikliğinden ziyade, mevcut sistemin ıslahı taraftarıdır. Siyasal olarak onarımcı-reformist (conservatist) ve korumacı-önleyici (preservatist) diye ayırt edilebilecek bir dizi sosyal hareket, bu bakış açısı içinde konumlanmaktadır.

Onarımcı reformist (conservatist) yaklaşıma göre, doğa, olması muhtemel ekolojik felaketler bakımından bizim için bir erken uyarı sistemi olabilir; doğa bizi besler ve canlı tutar. Biz doğa üzerinde faydalı deneyler yapabilir, onu kullanabilir, ondan estetik zevkler alabilir, rekreasyonel amaçlarla kullanabiliriz. Bu yaklaşımda doğa araçsal bir öneme sahiptir (Vincent, 2006, s. 344). Bu görüş aynı zamanda eko-kapitalizminde arka bahçesini oluşturur (Vincet, s. 359). Klasik liberal bir görüşten hareketle eko-kapitalizm, piyasanın gayreti ve tekniğin ilerlemesiyle ekolojik sorunların hallolabileceğine, devletin ise burada korumacı önlemler ve cezai yaptırımlarla doğayı korumada belli bir görev sahibi olduğu fikrini savunur. Kirliliği kaçınılmaz olarak gören korumacı-onarımcı anlayış, verilen zararı azaltmaya veya gidermeye odaklanmaktadır. Mesela maden çıkarılan alanlarda kesilen ağaçların yerine yenilerinin dikilmesi, alandaki ağır metallerin giderilmesi, toprağın rehabilitasyonu gibi çözüm önerileri sunarlar. Tazminat, "kirleten öder" prensibi gibi cezai yaptırımlarla da devlet aracılığıyla kirlenmeyi engellemeye çalışırlar.

Yine insan merkezci bakış açısı içerisinde kalmasına rağmen, çevresel değerlere daha hassas bir grup önleyici (preservatist) çevrecilerdir. Bunlar, kirlilik gerçekleştikten sonra değil, daha gerçekleşmeden önce (ex ante), bilimsel verilerin de yardımı ile önlem alarak olası kirliliği engellemek amacındadırlar. Kaynakta azaltma, düşük enerjili motorlar üretme, geri-dönüşüm, tekrar-kullanım, alternatif enerji kaynakları gibi daha geniş görüşlü yöntemlerle çevresel kirliliği önlemeye çalışırlar. Almanya, Hollanda, İsveç, Japonya gibi ülkeler daha çok bu yaklaşım üzerinden çevre politikalarını belirlemektedirler (Keleş ve ark., 2006, s. 351). Yine de görüleceği üzere, kaynaklardan daha fazla faydalanma, gelecek nesilleri koruma gibi amaçlarıyla bu yaklaşımda insanı merkeze almaktadır.

\section{Sürdürülebilir Kalkınma Yaklaşımları}

İnsan merkezci yaklaşımlar içinde doğa merkezciliğe en çok yaklaşanı, sürdürülebilir kalkınma anlayışıdır. Rio de Jenerio'da düzenlenen 1992'deki Birleşmiş Milletler Çevre ve Kalkınma konulu konferansta, "sürdürülebilir kalkınma" kavramı ortaya atılmıştır. Bu kavram çerçevesinde, doğa ile uyum içinde çevreye minimum zarar verecek yeni bir ekonomi anlayışı geliştirmek, gelir adaletsizliğini azaltmak, yenilenebilir kaynakların geliştirilmesine ve yaygınlaşmasına destek vermek gibi hedefler belirlenmiştir.

Fakat sürdürülebilir kalkınma yaklaşımı, kolaylıkça görülebileceği üzere kapitalizm için yeni bir pazar sağlamıştır. Son yıllarca ortaya çıkan ve giderek ülkemizde de rağbet gören yeşil kapitalizm (green capitalism), sürdürülebilir yaklaşımları benimseyerek, çevresel duyarlııklar üzerinden pazar sahasını genişletmektedir. Yeni ve "daha ekolojik" ileri teknoloji ürünlerle pazara yeni mallar arz etmekte, organik sebze meyve, doğal yiyecekler, ekolojik gibi yeni ekolojik trendler yaratarak kendini geliştirmektedir. 


\section{Minberin Çevreciliği}

Hutbelerde çevre konusunun ele alınışına olgusal olarak baktığımızda, karşımıza bu tarifler açısından karmaşık bir tablo çıkmaktadır. Son on yılda İstanbul Müftülüğü tarafından yayınlanan cuma hutbelerini analiz ettiğimizde, bir yere kadar tam anlamıyla insan-merkezci-reformist çevrecilik anlayışı, yani hükümet politikaları ve ekonomik sistemin talepleriyle örtüşen hutbeleri görürken, yakın tarihlerde, minber kendisini neredeyse "epistemik kopuş" olarak bile adlandırabilecek bambaşka bir pozisyonda konumlandırmaktadır. Bu zihniyet değişimi, ilerleyen sayfalarda incelenecektir.

Diyanet'in hutbelerinin doğa tanımlaması, Allah tarafından önceden konulmuş bir düzen içerisinde işleyen eksiksiz bir ekolojik makine, Newtonyen bir dünyadır. Konu, şu şekilde zikredilir:

"Yüce Allah, insanın da içinde bulunduğu âlemi canlı ve cansız varlıklarıyla birlikte bir düzen ve denge içerisinde yaratmıştır. Canlıların hayatlarının sürdürülebilmesi için bu düzen ideal olup onda herhangi bir eksiklik söz konusu değildir" (İstanbul Müftülüğü, 2005a).

Bu eksiksiz düzen, tüm eczası ile insan emrine tahsis edilmiş, tüm varlıklardan ayrı olan insanoğlu insanın kullanımına tahsis edilmiştir. Farklı hutbelerde bu yaklaşım sürdürülür:

"Bütün yaratılmışların en mükemmeli olan insanı diğerlerinden üstün ve hâkim bir konumda yaratmıştır... ...Bütün mahlukatın, insanın hizmetine verildiği bir gerçektir" (İstanbul Müftülüğü, 2002a).

"Her şeyi yoktan var eden Yüce Allah, hiçbir varlıkta bulunmayan özellik ve yetenekleri bir lütuf olarak insanoğluna vermiştir. Ayrıca varlıkların birçoğu, yine onun hizmetine sunulmuştur" (İstanbul Müftülüğü, 2003a).

İnsan doğanın bir parçası değil, doğanın efendisi, ondan üstün ve ona hâkim bir konumda yer almaktadır ve her varlık onun için yaratılmıştır, şeklinde bir anlayış vardır hutbelerde. Fakat, her şeyin insan faydası için yaratıldığını iddia eden bir görüş, insana zarar veren muzır canlıların varoluş sebebini açıklamakta zorlanacaktır. Bu felsefi sorunu bir yana bırakırsak, açıkça görüldüğü üzere Diyanet'in doğa-içerisinde-insan anlayışından ziyade, doğa-üzerinde-insan yaklaşımına yakın olduğu ve bu sebeple insan-merkezci yaklaşımın felsefi kökenine tabi olduğunu söyleyebiliriz. Althusser'in belirttiği gibi hümanizma ideolojisinin her şeyin merkezinde insan nosyonu, burada karşımıza çıkmakta, ideolojik devlet aygıtı olarak işlemektedir. İnsan doğada ayrıcalıklı konuma bir kez yerleştirildiğinde, artık insan-olmayan (non-human) her şey, insana göre anlam bulacak ve insanın türünün yararlanması için bir "kaynak" olarak görülecektir. Bu araçsal yaklaşım çok defa zikredilmiştir:

"Kara ve denizlerde yaşayan binlerce canlı türünden hiç birisi başıboş ve gereksiz yere yaratılmış değildir. Rabbimiz, bunların her birini bizim için, ya bir deva 
olması veya bir ihtiyacımızı gidermesi için lütfetmiştir" (İstanbul Müftülüğü, 2002a).

"Havaya, suya ve gıdaya intiyacımız olduğu gibi, ağaçlara, ormanlara ve yeşil alanlara da ihtiyacımız vardır" (İstanbul Müftülüğü, 2004a).

"Yararımıza sunulan her nimet, aynı zamanda Allah'ın sorumluluğumuza verdiği bir emanettir. Şüphesiz çevre de bunların arasındadır" (İstanbul Müftülüğü, 2005a).

Doğa, emrimize ram edilmiş bir emanettir. Burada, aslında emanet edilmek ile emrine verilmek arasındaki çelişik anlam da göz ardı edilmektedir. Yine bu çelişkiyi mevzu bahis etmeden geçerek, "Hutbelere göre emrimize verilmiş olan doğa nedir?" sorusuna eğilelim. Doğa, ihtiyaçlarımızı karşılamak üzere dizayn edilmiş bir kaynaktır, bizim ve gelecek nesillerimizin faydasına sunulmuştur. Fiziksel ve ekonomik bir araç, koruyucu bir mekân, rekreasyonel amaçlar için kullanılacak bir alan yahut tefekkür ve temaşa için var olan bir fon vazifesi gören doğa, aynı zamanda "ulusal bir değerimiz"dir. Doğaya araçsal yaklaşım, ayetlerle de desteklenmiştir:

"Doğrusu biz sizi yeryüzüne yerleştirdik ve orada size geçim kaynakları sağladık"3 (İstanbul Müftülüğü, 2002a).

"Hâlbuki canlılar, sadece bize ait değildir. Bizden sonra gelecek nesillerinde bunlarda hakları vardır" (İstanbul Müftülüğü, 2002a).

Yine bu dönemdeki hutbelere göre Doğa, ekonomik ve rekreasyonel faydalara sahip ulusal bir değerimiz olması hasebiyle korunmayı hak etmektedir ve çevre bilincine sahip olmak, "cennet vatanımızı korumak" şeklinde bir vatanperver algı içerisinde sunulmaktadır:

"Teneffüs ettiğimiz havadan içtiğimiz suya, okuduğumuz kitaptan yazdığımız kaleme kadar birçok alanda ağaçların varlığını görüyoruz. Toprağın erozyon yoluyla denizlere dökülmesini ormanlar önler. Ormansız yerlerde şiddetli yağmur nedeniyle can ve mal kayıpları olur" (İstanbul Müftülüğü, 2004a).

"Rengârenk çiçekleri, yeşillikleri, tertemiz havası, suyu ve cıvıl cıvıl öten kuşlarılyla tabiat, ruhumuzu dinlendirmektedir. Ağaçlar ve ormanlar bir ülkenin zenginlik kaynağıdır. ...Cennet vatanımızın çölleşmesine seyirci kalmayalım" (İstanbul Müftülüğü, 2004a).

"Çevreyi kirleten, doğal zenginlikleri sorumsuz ve ölçüsüzce kullanan kimseler, dolaylı olarak diğer insanlara zarar verir" (İstanbul Müftülüğü, 2006).

3 Kur'an-ı Kerim, Araf, 7/10. Alıntılandığı yer (İstanbul Müftülüğü, 2003a). Bu bir ayet olmasına rağmen, ayetin kullanıldığı bağlam, çevirideki sözcük seçimleri gibi faktörler sebebiyle analize dâhil etmeyi uygun gördüm. Görüleceği üzere, hutbelerde kullanılan ve sürekli tekrar edilen belli başlı ayetler vardır. Çevre sorunu, bu ayetler bağlamında kodlanılır sürekli. Hâlbuki Diyanet'in paradigmasını değiştirdiği 2007 sonrası hutbelerde kullanılan ayetler, bunlardan farklıdır. Bu da ayetlerin seçiminin ve bağlamının önemini göstermektedir. 
Hutbelerde ifade edilen anlayışa göre, yaşamımız için Allah tarafından bize ve cennet vatanımıza lütfedilmiş doğa, maalesef ki çağımızda kirlenmekte ve dengesi bozulmaktadır. Çağdaş sorunları gündeme getiren hutbelere göre en önemli problemlerimizden biri, doğal dengenin bozulmasıdır.

"Çağımızın en önemli problemlerinden biri, çevre kirliliğine bağlı olarak doğal dengenin bozulmasıdır" (İstanbul Müftülüğü, 2006).

Fakat çağdaş küresel bir sorunun bir hamlede millî ölçeğe indirilmesi dikkat çekmektedir. Küresel olanla yerel olanın ilişkisi sorusunu yine bir kenara bırakıp milliyetçiliğin yukarıda bahsettiğimiz burjuva devlet ideolojisi içindeki yerine ve ideolojik aygıttaki tezahürüne dikkat çekmek istiyorum. Ayrıca muasır medeniyetlerdeki çağdaş sorunlara duyarlı ve fakat kozmopolitanizm tuzağına düşmeden operasyon yapan hutbe aygıtı, Cumhuriyetin başlangıcından beri, egemen yönetimsel devlet aygıtının niyetleriyle paralellik arz ettiği de görülmektedir.

Çevresel sorunlar hutbelerde kuru ve pedagojik bir dil ile sunulmakta, bu çağdaş sorun üzerinden dinin alanını genişletebilecek manevi bir teolojik öğreti geliştirebilmenin imkânı varken, bu imkânı basitçe sorumluluklar, ödevler, haklar bağlamında inceleyerek oluşturduğu deontolojik etik sebebiyle etki gücünü sınırlamaktadır. Önermiş olduğu rasyonalist, reformist çözümler, köklü bir ahlak geliştirmeye imkân sağlamamakta, doğanın akıllıca kullanıımasını salık veren, yeşil-kapitalizmin yeni sömürü sisteminin ilişkilerini, yeni-üretim ilişkilerini ideolojik dinsel bir aygıt olarak yeniden üretmektedir. Var olan sistemi değiştirmeye yönelmeden, aksine rasyonel müdahalelerle yeniden üretilmesi ve sürekliliğinin sağlanması amacına hizmet eden bu ideolojik dinsel aygıt, basit, gündelik çözümlere ve sığ bir çevrecilik anlayışıyla üretilmiş ödevlere dayalı bir çevrecilik geliştirmektedir. Hutbelerde, rasyonel araçsal kaygılardan hareketle, kaynak korumacı bir anlayış sergilenmeye başlamıştır:

“Dünyamızın yer altı ve yer üstü kaynaklarından istifade ederken kesinlikle israf etmemeliyiz... ...Sorumsuz biçimde tahrip etmek, tüketmek değil, büyük bir sorumlulukla hareket etmemiz gerekmektedir"(İstanbul Müftülüğü, 2002b).

"Ülkemizi, şehrimizi, kasabamızı, mahallemizi, cadde, park, ve sokaklarımızı, evlerimizin önlerini ve piknik yerlerini temiz tutalım. Çevremizi sigara izmariti, çekirdek kabuğu ve atıklarla kirletmeyelim" (İstanbul Müftülüğü, 2004b).

Yukarıda belirtildiği gibi, çevre bilinci ödevler ve haklar bağlamında ifade edilmiştir:

“...Insanlara, canlılara, tabiat ve çevreye karşı dinimizin emrettiği görev ve sorumlulukları yerine getirmenin bir ödev olduğu unutulmamalıdır" (İstanbul Müftülüğü, 2004a).

“Havayı, suyu ve toprağı kirletmek, çevreye zehirli atıklar bırakmak da birer kul hakkıdır" (İstanbul Müftülüğü, 2005b). 
Diyanetin çevrecilik tasavvuru, kaynak korumacı yahut onarımcı-reformist anlayışla sınırlıdır. Yaşam tarzını, evren tasavvurunu ve hayat felsefesini değiştirmeden gündelik hayat içerisinde yapılacak küçük değişiklikle kotarılabilecek, manevi bir duygu ile değil de, ekonomik ihtiyaçlar, sosyal haklar bağlamında ele alınan çevre sorumluluğunun kaynakları akıllıca kullanarak çözülebileceği düşünülmektedir. Doğa ile ilişki, sorumluluk, koruma, ödevler, görev gibi kavramlar aracılığı ile zikredilmekte, böylece doğa ile dışsal bir ilişki kurulmaktadır. Zaten hutbelerin tarihlerine dikkat edilirse, çevre ile ilgili hutbelerin Haziran ayında irat edildiği görülecektir. 5-11 Haziran'ın Çevre Koruma Haftası olması nedeniyle, çevre konusu da özellikle bu haftada ele alınmakta, yani samimi bir ilgiden ziyade haftanın önemine dair yapılmış mutat bir konuşma olarak icra edilmektedir.

Fakat ilginçtir ki hutbelerin çevre sorununu ele alışı, 2007 yılında âdeta sihirli bir değnek değmişçesine değişmiş; Diyanet, sığ ekolojizm denen insan-merkezci-korumacı anlayıştan daha derin bir anlayışa, derin ekolojik yaklaşıma, yakın sürdürülebilir bir çevrecilik düşüncesine geçmiştir. Haziran 2007'de okunan hutbede neredeyse Cumhuriyetin başından beri yerleşmiş olan insan-merkezci anlayış bir anda tersine çevrilmiş, hutbelerde tekrar edilmesi gelenek olmuş ayetler yerine bambaşka ayetler tercih edilmiştir.

"Varlıkları manevi yönden ve yaratılıştan kutsal görme, İslam çevreciliğinin manevi temelini oluşturur. 'Görmez misin ki; göklerde ve yerde olanlar, güneş, ay, yıldızlar, dağlar, ağaçlar, hayvanlar ve insanların bir çoğu Allah'a secde ediyor'[ Hac, 22/18]. 'Yeryüzünde yürüyen hayvanlar ve gökyüzünde iki kanadıyla uçan kuşlardan ne varsa hepsi sizin gibi birer topluluktur' [En'âm, 6/38]. Bu ayetlerden anlaşıldığı gibi kâinattaki tek varlık insan değildir. İnsanın diğer varlıklar karşısında sorumluluğu vardır. Peygamber Efendimizin şu hadisi, insanın bu sorumluluğunun inceliklerini ortaya koymaktadır: 'Otu bol yerlerde yolculuk yaptığınızda otlardan istifade etmeleri için hayvanlara (develere) imkân verin. Gece mola vereceğiniz zaman, yoldan ayrılıp bir kenara çekilin. Zira yol hayvanların geçeceği ve böceklerin geceleyeceği yerdir" [Müslim, "Imâre", 178]" (İstanbul Müftülüğü, 2007).

Görüldüğü gibi bu hutbede doğanın insana olan faydasını yeniden anlatılmaya başlanmamış, tam da derin bir anlayış içerisinde, doğanın kendinde ve kendi için değerli ve kutsal olduğunu söylenerek ve ilk defa bir eko-teolojik ahlakın temellerinden bahsederek, İslam çevreciliği tabiri gündeme getirilmiştir. Daha önce sürekli tekrarlanan "emrine verilme" ayeti yerine bu sefer, gökleri, ağaçları, hayvanları, Allahın ilahi-ontolojik yüceliğinin şemsiyesi altında eşitlenmiştir. Hayvanların ve kuşlarında birer topluluk, birer ümmet olduğunun belirtilmesi ile onları basitçe birer kaynak statüsünden çıkarıp insan gibi, Yaratıcı'nın bir kulu seviyesine çıkartılmıştır. Zikredilen hadiste de önceki dışsal ve soğuk, hizmet alanın hizmet verenden daha iyi faydalanması için hizmet vereni koruması ekseninde kurulmuş, ast-üst ilişkisine dayalı merhamet eden ve koruyan insan algısından; en az bir insan teki kadar dikkate alınması gereken diğer canlıların, hem de basitçe, binek hayvanları değil, böcekler ve karıncalara kadar tüm canlıların nazar-ı itibara alınması gerekliliğinin altı çizilmişstir. 
Daha önceki yıllarda gördüğümüz gibi hümanist ideolojinin hâkim olduğu insanın ayrıcalığı ve üstün konumu, burada bir anda tepetaklak edilmektedir.

"Doğal hayatın ve çevre kirliliğinin temel sorumlusu insan faaliyetleridir" (İstanbul Müftülüğü, 2007).

"Evet... İnsanoğlu çok zalim, çok nankör. Çünkü bütün canlılar içinde, israfta sınır tanımayacak kadar aşırı derecede tüketebilen tek varlık insandır" (İstanbul Müftülüğü, 2008).

Insan-merkezciliği rafa kaldıran bu yeni hutbelerde, eskiden sıkça tekrarlanan "musahhar kılınma" ayetini de yeniden ele alarak, bu ayetin yanlış yorumlandığı 2008'de ki hutbede belirtiliyor.

Ayrıca, bu senelerden itibaren hutbelerin dilinin değiştiği de gözlemlenebilir. 2007'de ilk kez "ekoloji" kelimesinin kullanıldığını görüyoruz. Bundan sonra hutbelerin eski, kalıplaşmış dili değiştirilerek yeni konulara yeni bir dil ile girilmeye başlamıştır. Bu tarihlerden sonra artık, çağdaşlaşma ülküsüne karşı biraz daha mesafeli durmaya başlanmış ve günümüzdeki sorunların modern zihniyetin sorunları olarak tanımlanıp, dini ve maneviyatı bir kurtuluş vesilesi olarak öne süren açılamalar yapılmaya başlanmıştır. Kullanılan dil, eskiye nazaran bir ölçüde felsefi derinliği olan bir dile evrilmiştir. Bundan sonra; "bilim", "teknoloji", "etik", "modern hayat", "sanayi", "ilerleme", "tüketim toplumu" gibi kavramlar metinlerde zikredilmeye başlamış, dahası çoğu zaman olumsuz bir kontekste anılmışlardır.

“...Bunlar, sadece teknolojik gelişmelerin ve modern hayat tarzının insanı mutlu edemediğini, madde ve mana arasındaki dengenin bozulduğunu göstermektedir" (İstanbul Müftülüğü, 2010a).

"Insanlık tarihinde bu kadar güçlenen inkârcı ve materyalist hareketlerin günümüz dünyasında ne kadar tahripkâr olduğunu, gelişmemiş ülkeler yanında "ileri" denen ülkelere bile ne ağır bedeller ödettiğini görmekteyiz" (İstanbul Müftülüğü, 2010a).

Daha önceki hutbelerde görülen ilerlemeye, kalkınmaya olan teşvik, burada tam tersine dönerek ileri ülkelerin sebep olduğu ekolojik sorunlara dikkat çekilmektedir. Dahası, hutbelerde, tüketim toplumu eleştirisi gibi entelektüel konular, akademik çalışmalar bağlamında zikredilerek ekolojik sorunun ciddiyetine farklı bir jargonla vurgu yapılmaktadır.

"Günümüzde sanayi ve kozmetik atıklarının hiçbir önlem alınmadan çevreye atılması gibi yanlış işlerle doğal zenginliklerimiz ve çevremiz tahrip edilmekte, doğal denge bozulmaktadır" (İstanbul Müftülüğü, 2009).

"Yabancı bir enstitünün yayımladığı bir raporda, aşırı tüketimin "dünyayı tükettiği" ifade ediliyor.... 'Dünya Doğal Hayat Fonu' adındaki bir kurumun doğal kaynaklar üzerine yaptığı bir araştırma raporu, günümüzdeki tüketim çıgınlığının, dünyanın sonunu hazırladığını bildiriyor; son otuz yılda dünya üzerindeki doğal 
kaynakların üçte birinin insanlar tarafından tüketildiği ifade ediliyor" (İstanbul Müftülüğü, 2008).

Minber, artık kendinden daha emin konuşmakta, Batı kültürünü eleştirme görevini üstlenmekte, cumhuriyetin kurucu idealleri olan sanayi toplumu, ilerleme, modernlik, bilim, teknoloji gibi kavramlara tabir-i caizse dudak bükmektedir. Yine eski tarz-ı lisanına mugayir olarak, daha maneviyat yüklü, daha coşkulu konuşmakta, kurucu ideallere karşı, unutulmuş olan dine yönelik Mesihsel bir çağrı yapmaktadır.

"Bizler, âlemlere, yani canlısıyla cansızıyla bütün varlıklara rahmet olarak gönderilmiş bir peygamberin ümmetiyiz. Böyle bir peygamberin ümmetine de ancak bütün varlıklara rahmetle yaklaşmak yaraşır; yıkmak, yakmak, yok etmek değil; yapmak, yaşatmak yaraşır" (İstanbul Müftülüğü, 2007).

"İman varsa, imkân da vardır. Hatırlayın: Âlemlere rahmet olarak gönderilen Efendimiz de cehaletin ve zulmün en yoğun olduğu bir ortamda gelmişti. Bir kişiydi. Hira'da hayat damarları kurumuş insanlığı diriltmek üzere görevlendirildiğinde sevgi ve merhameti öğretti insanlığa... Rahmet olup yağdı tüm mahlukata..." (İstanbul Müftülüğü, 2010a).

"Hz. Peygamber Medine şehrini, günümüzde "kent etiği" denilen ilkeler ve erdemlerle donattı; Bir yeri İslam şehri saymak yetmez. Bunun için bilgisiyle, irfanıyla, ahlakıyla, adabıyla, estetik anlayışıyla İslam kavramının içini dolduran değerlerin şehirde yaşayanların kişiliklerine, davranışlarına, insan ve çevre ilişkilerine sinmesi gerekir" (İstanbul Müftülüğü, 2010b).

Görüldüğü üzere, belirli bir tarihten sonra hutbelerin dilinde keskin bir değişim yaşanmıştır. Bu değişimin analiz edilmesinin, din-ekoloji-devlet ilişkisine dair bir takım kavrayışlar geliştirmemize imkân sağlayacağı kanaatindeyim.

\section{İdeolojik Dinsel Aygıtın Pratiği Olarak Cuma Hutbelerinde Çevre Konusunun İşlenişi Üzerinden Bir Analiz}

Althusser'in ideolojik aygıtları, ekonomik pratiğin şemsiyesi altında genellikle bir araya gelerek koordine çalışmalarına rağmen, her bir aygıt kendi otonomisine sahiptir. Dinsel aygıt, yönetsel aygıt ile her ne kadar işbirliği içerisinde olsa da iki aygıtın da birbirlerinden farklı, birbirleri ile çelişen tavır ve pratikleri vardır.

Cumhuriyet dönemi boyunca, dinî bir pratik olan hutbelerde görülen temel stratejinin en belirgin özelliği, Kemalist-Aydınlanmacı söylemle ters düşmemeye özen göstermesi, onla çatışmamaya dikkat etmesidir.

Hutbelerde, bir yandan resmî siyasal söylemin tezlerini hedef alan içerikten ve söylemlerden uzak durmaya çalışmak, öte yandan resmi söylemin genel dinî algıya ters düşecek müdahalelerine ve tanzimine engel olmaya çalışmak ve heterodoks yapılar 
tarafından meşruiyetine yapılan saldırılara karşı durabilmek gibi bir dizi hassasiyete özen gösterilmektedir. Başka bir ifade ile DiB, bir yandan yönetsel aygıt tarafından dinin dışlanmasını engellemek, bir yandan dinin meşru ve asıl temsilcisinin Diyanet kurumu olduğu algısını benimsetmek, öte taraftan heterodoks ve radikal gruplara karşı kamuoyu oluşturmak ve bir de "resmi söylem"in din algısı ile geleneksel halk dindarlığını uzlaştırmak gibi birçok tehlikelerle dolu mayınlı bir alanda mevcudiyetini sürdürmek durumunda kaldığı gözlemlenebilir. Tüm bunlarla dinamik bir ilişki içinde olan DiB, kendisine has özgün bir zeminde varlığını idame ettirme gayretindedir. Bu sıkışmışlık içerisinde, bunlarla birlikte ve bunlara karşı taktiksel ve stratejik yöntemler geliştirmektedir. İştar Gözaydın'ın da belirttiği üzere, Cumhuriyet tarihi boyunca, Türkiye Devleti'nin ideolojik bir araç olarak benimsediği kurumlardan biri olan Diyanet İşleri Başkanlığı, tüm diğer yapılarda olduğu gibi kendisini biçimlemeye çalışmış olan iktidarlara bir yandan kendi dinamiklerini üretmiştir (Gözaydın, 2009, s. 305).

Diyanet, gerilimli alanlardan kaçınarak, resmî söylemin boş bıraktığı alanları doldurmak ve bu boşlukları alabildiğince işleyerek dinî söylemin otantikliğini yeniden üretmek gayretine girişmiştir. "Resmî söylemin boş bıraktığı alanlar" aslında yönetsel aygıtın Diyanet'e terk ettiği konuları oluşturmaktadır ki, bunların sınırı yasal olarak da çizilmiştir. Örneğin, din işlerinden sorumlu kurumun adının Umur-u Diniye mi yoksa Umur-u Diyaniyye mi olacağı konusunda mecliste geçen bir tartışma da Samih Rıfat'ın argümanı, Diyanet'e bırakılan alanların anlaşılması açısından önem arz etmektedir. Şöyle der Rıfat:

"Din kelimesinde iktisadiyat, içtimaiyat, inzibat, tedrisatın cümlesi dâhildir. Bunların her biri hükümetin munkasım olduğu şubelere taksim edilmiştir. Meydanda kalan yalnız ibadat, itikadat, itfaya (fetva verme) ait olan ahkamdır ki Umur-ı Diyaniye Riyaseti'ne aittir. Ve diyanet kelimesi tamamıla bu manaya mevzudur" (Kara, 2008, s. 63).

Ayrıca anayasaya 1965 ve 1982 yıllarında eklenen maddelerde de Diyanet İşleri'nin görev ve sorumlulukları belirlenip söz sahibi olabileceği alanların sınırları çizilmiştir. 1965 tarihli ve 633 sayılı Diyanet İşleri Başkanlığı Kuruluş ve Görevleri Hakkında Kanun'a göre; Diyanet'in görevleri: "İslam inançlar, ibadet ve ahlak esasları ile ilgili işleri yürütmek, din konusunda toplumu aydınlatmak ve ibadet yerlerini yönetmek olarak belirtilmiştir. 1982 yılındaki yeni maddeye göre; “Genel İdare içinde yer alan Diyanet İşleri Başkanlığı, laiklik ilkesi doğrultusunda, bütün siyasi görüş ve düşünüşlerin dışında kalarak ve milletçe dayanışma ve bütünleşmeyi amaç edinerek, özel kanunda gösterilen görevleri" yerine getirir.

Diyanet'e "ilmihal Müslümanlığı" alanının tanzimi konusu tahsis edilmiş, diğer konularda ise devletin resmî söylemini aynen tekrarlaması istenmiştir. Diyanet'in genel amacı, hurafelerden arınmış dinî bilgi ve kültür verme ve dinin devlet, Cumhuriyet ideolojisi ve inkılaplarıyla bir şekilde uzlaştırılmasıdır (Kara, 2008, s. 77). O halde, hutbelerin tarihsel gelişimi ve içeriğinin şekillenmesinde üç saik rol oynamıştır diyebiliriz: 
(1) Radikal İslam'ın reddi: Heterdoks gruplardan kaynaklanabilecek her türlü olumsuzluğun, özellikle yönetsel aygıtın din üzerine yönelebilecek gazabına mani olma amacına matuf olarak radikal İslam'la savaşmış, kendi meşruiyetini sağlamlaştırma gayretine girişmiştir.

(2) "Volk İslam"ın tadil ve tanzimi: Başından itibaren hutbeler yoluyla Diyanet, halk arasında yaygın hurafelerin ve mitik inanışların tasfiye edilmesine gayret göstermiş, bunların modernite ile uyuşmayan taraflarını rasyonel kitabi bir zeminde fıkhı-Sünnilik ekseninde tadil ve terbiye etmeyi vazife edinmiştir. Aydınlanmacı-Pozitivist-Seküler resmi söylemin hoşlanmadığı "volk İslam"ı (Mardin, 2010, s. 149). Cumhuriyetin aydınlarının arzu ettiği dini formasyonla yer değiştirmeye çalışmıştır. İsmail Kara, meseleyi daha da açarak şöyle demektedir:

“Diyanet'in dinin algılanma ve yaşanma tarzı üzerinden halk dindarlığı ile bu tür dindarlığı besleyen cemaat ve tarikatlara karşı yürüttüğü mücadele, aslında Diyanet'le veya Cumhuriyet'le başlamış bir şey değildir. Bunun köklerinin 19. ve 20. yüzyıl Müslüman aydınlarında aramak gerekir. 19. yüzyıl pozitivizminin, Protestanlığın ve yeni Selefiliğin esas iddialarını ve tortularını taşıyan bu bakış açısını, bugün bile halk dindarlığı üzerinde bir baskı ve dönüştürme aracı olarak kullanıldığı/ kullanılmaya icbar edildiği görülmektedir" (Kara, 2008, s. 79).

(3) Siyasal aygıtın boşluklarını doldurmak: Hutbeler, gerilim hattından kaçınmak ve aynı zamanda kendine bir yaşam alanı açmak amacıyla, siyasal aygıtın doğrudan orada olmadığı alanlara yoğun bir ilgi göstermektedir. Alkol sorunu, kumar, aile içi yardımlaşma, misyonerlikle mücadele gibi konularla birlikte, konumuz olan çevre sorunu da bu metruk alanlara örnektir.

Diyanet'in bu küçük alanlar üzerinden kendine bir yaşam alanı oluşturduğu iddia edilebilir. Ankara'nın görmek istediği Diyanet kavramının tasallutundan azade olan bu alanda, Diyanet kendi manevra alanını oluşturmaktadır. Fakat görüldüğü üzere, başından itibaren konunun ehemmiyetini kavrayamayan Diyanet, çevre sorunu üzerinden esaslı bir eleştiriye girişememiş, gelecek yüzyıllarda felsefi-kelami açılımlara kapı aralayabilecek teolojik bir tenkide girişmemiştir. Bahsi geçen hutbelerde görüldüğü üzere, yönetsel aygıtla ve pazarla tamamen uyum içerisindedir. Ayrıca dinsel duygu atmosferinin iyi kurgulandığı, yönlendirici ve ikna edici bir üsluptan ziyade, soğuk ve yapay bir dille, ilkel ve basit analojilerle, ödevler, zorunluluklar, bağlamında konuyu ele almıştır.

Fakat yukarıda gördüğümüz gibi Diyanet, hutbelerdeki dilini belli bir tarihten itibaren keskin bir şekilde değiştirmiş, resmî ideolojinin kurucu ideallerine ters düşecek bir anlayış geliştirmiş, öncesinde göremediğimiz yoğunluklu manevi dili kullanma çabasına girişmiştir. Diyanet, kendine ayrılan bu küçük alanın ehemmiyetinin belki de farkına vararak, çevre konusu üzerinden dinin alanının genişletilebileceğini, çağın sorunlarına hayat vermek için dinin Mesihsel geri dönüşünün bu yolla mümkün olabileceğini 
düşünmüş, resmi söylemin kendine bıraktığı alanda kendisine bir "yaşama alanı" yaratma gayretine girişmiştir. Dini ideolojik aygıt konu üzerinde özerk konumu güçlendirmektedir. Batı'da kilisenin bu konu üzerinde ihtimamını da örnek alan Diyanet, hutbelerde ortaya koyduğu üzere, kendi minimal alanında gelenek, resmî ideoloji ve radikalizmin sıkıştırmaları yanında çevre sorunu üzerinden kendisine bir "yaşam alanı", güçlenebilmek için ayağını basacağı güçlü bir zemin bulabilmiştir.

\section{Sonuç}

Cuma hutbeleri, Althusser'in ideoloji kuramı bağlamında, ideolojik devlet aygıtı olarak ele alınabilir. Althusser'in verdiği kilise örneğinde olduğu gibi, Diyanet; zaten hep özne olan bireyleri, Mutlak Özne ve Devlet adına, özne olarak çağırır. Bu suretle Diyanet, devlet aygıtlarının asli vazifesi olan; milliyetçilik, hümanizm, kapitalizm gibi burjuva değerlerinin ikame edilmesinde aşırı-belirlenimin bir öğesi olarak yerini alır.

İdeolojik aygıtlar ve baskı aygıtları, en nihayetinde eşgüdümlü çalışmalarına rağmen, her aygıt kendi otonomisine sahiptir ve aygıtlar birbiri ile çelişebilir. Analizimizde ortaya konduğu gibi, çevre mevzuunda ilkin Aydınlanmacı-Kemalist kurucu felsefe ile aynı minvalde olan hutbeler, belirli bir kırılma döneminden sonra bu aydınlanmacı, Newtonyen çerçeveden uzaklaşarak, daha doğa merkezci zaviyeden sürdürülebilir kalkınmacı bir ekolojik yaklaşıma evrilmiştir.

Hutbelerde çevre konusunun mevzubahis edilmesinin sebebi ise diğer aygıtların çevre gibi bir takım alanları Diyanet'e terk etmiş olmasıdır. Misyonerlikle mücadele, alkolle savaş, çevrecilik gibi konularda devletin diğer aygıtları doğrudan aktif şekilde iş görmemekte; devlet, bu alanları zımnen Diyanet'e terk etmektedir. Diyanet bu dar alanda, resmî ideoloji, halk İslam'ı ve radikal İslam kıskancında manevralar yapmaya çalışmakta, tam da bu alanlarda kendi mevcudiyetini ve otonomisini sürdürmeye çalışmaktadır. Özellikle Batı'da ve diğer dinlerin ilahiyatlarında geniş yankı bulan ekoloji konusunda da Diyanet 2007 'den itibaren daha hassas bir şekilde durmakta, kendine terk edilen alanı sadece kullanmakla kalmayıp bu alanda yeni yaşama imkânları bulmaya çalışmaktadır. Illeride, özelde hutbelerde ve genelde Diyanet yayınlarında, toplumsal cinsiyet, çevrecilik gibi konuların daha fazla ve daha güçlü bir şekilde ele alınacağı öngörülebilir. Kuruluşundan beri, çağın gerçekleri ile yüzleşmek zorunda kalan Diyanet'in, "IImihal Müslümanlığı" konularından, şehirli ve okumuş cemaatin de artması nedeniyle, daha güncel konulara yöneleceği, bu yönelişin eskiye nazaran daha sahici ve özgüvenli olabileceğini öngörebiliriz. 


\title{
Looking to Environment from the Perspective of Pulpit: Presentation of the Issue of Environment in Friday Sermons
}

\author{
Metin Demir*
}

Every week millions of people perform the Friday prayer in Turkey (Acar, 2003). As a means of public communication, the Friday khutbahs, which is an essential duty (fard) of Friday prayer itself" (Baktır, 1998, p. 425; Çakan, 1975, p. 26-27) have a sociological, communicational, pedagogical (Döner, 2004; Suna, 1996) and political importance. Every week, it has ability to reach a great portion of population that most the cutting age communicational technologies cannot achieve. Thus, it is asserted that Friday sermons cannot only be considered to be a part of worship, but they must also be understood in terms of politics, ideology, and philosophy. Sermons represent one of the most common and concrete example of the metaphysic of present by depending the presence of the sermon giver in order to warrant the veracity of what is talking about. The sanctity of Logos or spoken words, which comes from a Logo-centric tradition, is the hidden cause of concern and confidence in sermons.

Apart from this philosophical base, Friday sermons have always played a political role in Islamic tradition (Baktır 1998, p. 425). Political authorities have used it as a means of legitimization and the Muslim public has obeyed the power of to those whose names are made reference in the sermons (Baktır, p. 426). After the fall of the Ottoman Empire, the secular Turkish Republic has impinged on the deliverance of sermons and has used them for its own purposes. Several different issues targeted by the modern Republic include: militarism (Akseki, 1937, p. 200; Usta, 2005, p. 225), economic development (İstanbul Müftülüğü, 2004d), and patriotism (Akseki, p. 307, Diyanet İşleri Başkanlığı, 1981, p. 497; Vahid, 1928, p. 29, İstanbul Müftülüğü, 2003b) along with the foundational ideals of the Republic such as the importance of scientific and technological advancements (Vahid, p. 138) and technological development (Akseki, p. 7) or the value of the regime (İstanbul Müftülüğü, 2004c). As it can be seen sermons that generally handle apolitical issues, but sometimes become a directly articulated political discourse.

* M. A. Student, Istanbul Sehir University, Department of Cultural Studies Correspondence: vmetindemir@gmail.com 
This paper focuses on a seemingly apolitical matter, i.e. the presentation of the issue of environment in sermon topics. The issue is seen as inessential at first glance, but it is claimed that ideological operations especially appear in these supposedly trivial issues. As mentioned, the use of political issues such as, militarism, and patriotism is obvious; what this paper seeks to explore is the ideological operation at work in sermons through the issue of environment and by doing so it is aimed to develop a degree of insight toward the relationship between the state- religion and ecology. It is asked how the state and religion interact with each other and violate one another's sphere of jurisdiction by means of environmental crises. To explore this issue, a certain definition of ideology is necessary. Since there are dozens of versions that may be used (Eagleton, 1996), Althusser's concept of ideology and ideological state apparatuses is espoused here. This preference is simply an operational manner. Thus, the question is whether Friday sermons may be evaluated as being ideological apparatuses in Althusserian understanding?

The Althusserian theory of ideology is a variant of Marxism (Muck, 2003, p. 183). Its difference stems from its taking the texts by young Marx text based on Spinoza, as its foundation rather than Hegel (Tura, 1990, p. 27). Althusser objects to historicism and humanism in the Marxist tradition for the reason that the concept of subject used by Marx does not refers to the abstract consciousness and alienation but rather it is constituted by the very practices of relations of production (Muck, p. 133). Turning away from Feuerbach's notion of alienation and from the Hegelian Notion of humanity that resembles a universal geist, Marx later focused on structural explanation of notions in terms of relation and power of production, economical determinism, superstructure and the state. Althusser calls this changing as "epistemological rapture," that is, Marx passes from ideology to science (Tura, p. 32).

For Althusser, ideology has certain basic features. First, ideology has no history, because it is retained in every social and historical structure (Althusser, 2010, p. 197). Second, it is an indispensible social formation for every society (Lock, 1996, p. 75). Third, ideology represents the imaginary relationship of individuals with their real conditions of existence. Although it is in an imaginary form, it is concerned with materiality, and ideology has a material existence. An ideology always exists in an apparatus and its practice, or practices. This existence is material (Althusser, pp. 92-93), where only a single subject (such and such an individual) is concerned, the existence of the ideas of his belief is material in that his ideas are his material actions inserted into material practices governed by material rituals which are themselves defined by the material ideological apparatus from which derive the ideas of that subject (p. 98). Then, Althusser made his heady thesis that ideology interpellates the individuals as a subject (p. 99). There is no ideology except for concrete subjects, and this destination for ideology is only made possible by the subject: the category of the subject is only constitutive of all ideology insofar as all ideology has the 
function (which defines it) of 'constituting' concrete individuals as subjects. For Althusser, individuals are always already a subject and they constantly acknowledge the rule of recognition. He explains this process of recognition and interpellation in the example of Christian religious ideology (p. 109). Then, he inferred the rule from this example:

The duplicate mirror-structure of ideology ensures simultaneously:

1. The interpellation of 'individuals' as subjects;

2. Their subjection to the Subject;

3. The mutual recognition of subjects and the Subject, the subjects' recognition of each other, and finally the subject's recognition of himself;

4. The absolute guarantee that everything really is so, and that on condition that the subjects recognize what they are and behave accordingly, everything will be all right; Amen 'So be it' (Althusser, 2010, p. 207).

In the case of Friday sermons, the sermon giver (imam/khāțib) interpellates attendants as subjects by saying "honorable Muslim" and appropriating them as Muslims. In doing this, he has subjected them in front of the Absolute Subject, and then the mutual recognition of the Subject and subjects takes place. In the course of all these practices, the khāțib is preaching in the name of God and the state, because he is a state-approved religious official. Hence, it is asserted that Friday sermons can be handled as ideological state apparatuses, because the state speaks to the public through sermons. Ideological apparatuses work for the subjectification of individuals and also appropriate subjects into their due position through their function of over-determination (Sancar, 2008, p. 53). They help to reproduce the existing relation of production and power. There are two different types of ideological apparatuses: Repressive State Apparatuses (such as the army, police, courts et cetera) and Ideological State Apparatuses (such as the media, school, Church et cetera) (Althusser, 2010, p. 17). Although repressive apparatuses constitute a concrete body, ideological ones are retained in diverse areas and these ideological apparatuses function to reshapes our preferences, desires and thereby appropriate us into the web of power relations (Althusser, p. 56, 156). They inject the virtues of a bourgeois state, such as nationalism, economism, liberalism and humanism (p. 59). The world is integrated in to Capital by means of ideological apparatuses (Negri, 1996, p. 57).

After questioning the appropriateness of Althusserian notions of ideology for Friday sermons, it is examined in which perspective Friday sermon represent the problem of environment in terms of environmentalist movements. Therefore, different basic perspective environmentalism is given.

Environmentalism as a political and ideational movement arose after the Second World War (Ceritli, 1998, p. 256). However, there is no single standpoint within the environmental movement. The basic types are presented here: 
The eco-centric approach, claims that, nature has a certain number of rights regardless of human consumption, and that humans have no priority or special position over other parts of nature (Keleş, Hamamcı, \& Çoban, 2006, p. 294). Eco-socialism, eco-anarchism (Boockhin, 2010), eco-feminism (Salleh, 1997) are all examples of such radical movements that can be evaluated within the scope of an eco-centric approach.

The second type is the anthropocentric approach, which claims that nature has only meaning as soon as it services to the benefit of human. Nature is regarded here as a "source" for human survival. According to this approach, for this and future generations' survival, humanity must exploit natural resources in a reasonable manner. This movement is termed as conservatist and preservatist environmentalism which gives importance to preserving and renewing natural resources (Vincet, 2006, p. 359). Many European countries designate their policies according to this understanding (Keleş et al., 2006, p. 351).

The third type is sustainable development which seeks to find environmentally nonhazardous technologies and a way in which nature and human purposes can coexist without loss or damage.

If the understanding of environmentalism presented in sermons is examined, it will be seen that the concept of nature is a pre-determined Newtonian machine, which works as an ordered mechanism (İstanbul Müftülüğü, 2005a). This machine is given by God to humans, who are at the top of the hierarchy of living beings, and which is at the disposal (İstanbul Müftülüğü, 2002a, 2003a). Sermons present the human as a being over other parts of nature who is the master of the universe and that everything attains its true value and meaning to the extent of its servitude to humanity (İstanbul Müftülüğü, 2002a, 2002b, 2004a, 2004b, 2005a). Sermons' approach to nature is instrumental, where nature is mentioned as a resource, as a medium to live, as a recreational beauty or as an economic value (İstanbul Müftülüğü, 2004a, 2006). It also reduces global ecological crises to national problems (İstanbul Müftülüğü, 2006). Sermons also have soulless language, which always talks about on duties and responsibilities (İstanbul Müftülüğü, 2005b). As it can be seen the vision of Diyanet on the environmentalism is limited to a restorative-reformist, or source-conservatist, anthropo- centric approach.

As seen, the vision of the Diyanet on environmentalism is limited to a restorative-reformist, or resource-conservatist, anthropocentric approach.

Interestingly however, the discourse used in sermons changed dramatically after 2007. It passed from a narrow human-centrism supported since the beginning of the Turkish Republic to being nature-centrism. From that time on, nature has been represented as a being with its own rights, and not only as a slave of human utility. With this change of discourse, the possibility for the foundation an eco-theological ethics was launched. The conception of human as the master of nature has been rejected and considered as 
being destructive and in which humanity is targeted as responsible for environmental crises (İstanbul Müftülüğü, 2007, 2008). Furthermore, the material, technological and scientific developments, which had been earlier exalted, have now been condemned for the reason that they break the natural order. Moreover, a number of intellectual notions became to appear in a pejorative meaning, such as city life, modern life ethics, technology, industrial waste, consumer society et cetera (İstanbul Müftülüğü, 2008, 2009, 2010a). The minbar (pulpit) begins to criticize Western values, and contrary to a previously familiar language, it begins to speak more spiritually and enthusiastically. It begins to make a Messianic invitation to the forgotten aspect of religion which is contrary to the foundational ideals of the Republic (İstanbul Müftülüğü, 2007, 2010a, 2010b).

This change in discourse may point out some important insights on the relation between religion and the state. Althusser states that ideological apparatuses have their own autonomy; they sometimes go hand in hand with other apparatuses and giving birth to contradictions. It has been shown that, whereas the Diyanet, through its sermons, reflects the main characteristics of a Kemalist- Enlightened discourse until a certain time, it obtains its autonomy to make a room for rejoice of religion by means of environmentalism. It is claimed in this paper, that the Diyanet always oscillates between three things: first, it avoids to violating the state's ideals, second, it rejects of heretic-radical Islam, and third, it seeks to rectify folk Islam (Gözaydın, 2009, p. 305; Kara, 2008, p. 77; Mardin, 2010, p. 149). It seeks to make room for itself in this uncanny situation, and in doing so; it chooses certain specific issues that the state leaves to the discretion of the Diyanet (Kara, p. 63), including protecting the environment, family structure, homosexuality, fighting against alcohol and unchastity. As a conclusion, it is put forward in this article, Diyanet, as it can be seen in Friday Sermons since a certain time, strives to rejoice religion and to make a living space for itself.

Finally, it is put forward in this article that the Diyanet, as it can be seen in Friday sermons since a certain time, strives to instill a feeling of rejoice in religion and to carve out a living space for itself.

\section{Kaynakça / References}

Acar, E. (2003). Kalelioğlu: Devletin mesajını cuma hutbeleriyle verdik. http://arsiv.zaman.com. tr/2003/06/13/haberler/h7.htm adresinden 22.06.2011 tarihinde edinilmiştir.

Akseki, A. H. (1937). Yeni hutbelerim. Ankara: II. Cumhuriyet Matbaası.

Althusser, L. (2010). İdeoloji ve devletin ideolojik aygıtları (çev. A. Tümertekin). İstanbul: İthaki Yayınları.

Baktır, M. (1998). Hutbe. Diyanet İslam Ansiklopedisi içinde (c. 18, s. 425-428). İstanbul: Diyanet İşleri Başkanlığı Yayınları.

Bookchin, M. (2010). Özgürlüğün ekolojisi, hiyerarşinin ortaya çıkısı ve çözülüşü (çev. A. Türker). İstanbul: Ayrıntı Yayınları. 
Ceritli, İ. (1998). Çevreci hareketin siyasallaşma süreci. Divan IIlmi Araştırmalar, 2, 255-270.

Çakan, L. İ. (1975). Örnekleriyle uygulamali dini hitabet. Ankara: Kuşak Yayınları.

Diyanet İşleri Başkanlığı. (1981). Hutbeler. Ankara: Ayyıldız Matbaası.

Döner, M. (2004). Yaygın din eğitiminde hutbelerin rolü. Yayımlanmamış yüksek lisans tezi, Uludağ Üniversitesi, Sosyal Bilimler Enstitüsü, Bursa.

Eagleton, T. (1996). İdeoloji (çev. M. Özcan). İstanbul: Ayrıntı Yayınları.

Gözaydın, İ. (2009). Diyanet: Türkiye Cumhuriyetinde dinin tanzimi. İstanbul: Illetişim Yayınları.

İstanbul Müftülüğü. (2002a). İslam'ın insana bakışı. http://istanbulmuftulugu.gov.tr/hutbeler adresinden 20.06.2011 tarihinde edinilmiştir.

İstanbul Müftülüğü. (2002b). Kâinattaki ilahi dengeyi koruyalım. http://istanbulmuftulugu.gov.tr/hutbeler adresinden 20.06.2011 tarihinde edinilmiştir.

İstanbul Müftülüğü. (2003a). Doğal hayatı korumak. http://istanbulmuftulugu.gov.tr/hutbeler adresinden 20.06.2011 tarihinde edinilmiştir.

İstanbul Müftülüğü. (2003b). Vatan, millet, devlet... ilelebet. http://istanbulmuftulugu.gov.tr/hutbeler adresinden 20.06.2011 tarihinde edinilmiştir.

İstanbul Müftülüğü. (2004a). Tabiata ve çevreye karşı sorumluluklarımız. http://istanbulmuftulugu.gov.tr/ hutbeler adresinden 20.06.2011 tarihinde edinilmiştir.

İstanbul Müftülüğü. (2004b). Temizlik. http://istanbulmuftulugu.gov.tr/hutbeler adresinden 20.06.2011 tarihinde edinilmiştir.

İstanbul Müftülüğü. (2004c). Toplumsal iradenin temsili: Cumhuriyet. http://istanbulmuftulugu.gov.tr/ hutbeler adresinden 20.06.2011 tarihinde edinilmiştir.

İstanbul Müftülüğü. (2004d). Ülkemizi kalkındırmak toplumsal bir görevdir. http://istanbulmuftulugu.gov. $\mathrm{tr} /$ hutbeler adresinden 20.06.2011 tarihinde edinilmiştir.

İstanbul Müftülüğü. (2005a). Çevre sorumluluğu. http://istanbulmuftulugu.gov.tr/hutbeler adresinden 20.06.2011 tarihinde edinilmiştir.

İstanbul Müftülüğü. (2005b). Haklara duyarlı olalım. http://istanbulmuftulugu.gov.tr/hutbeler adresinden 20.06.2011 tarihinde edinilmiştir.

İstanbul Müftülüğü. (2006). Çevre sorumluluğu. http://istanbulmuftulugu.gov.tr/hutbeler adresinden 20.06.2011 tarihinde edinilmiştir.

İstanbul Müftülüğü. (2007). Hayvan ve çevre hakkı. http://istanbulmuftulugu.gov.tr/hutbeler adresinden 20.06.2011 tarihinde edinilmiştir.

İstanbul Müftülüğü. (2008). Su ve israf. http://istanbulmuftulugu.gov.tr/hutbeler adresinden 20.06.2011 tarihinde edinilmiştir.

İstanbul Müftülüğü. (2009). Çevre bilinci. http://istanbulmuftulugu.gov.tr/hutbeler adresinden 20.06.2011 tarihinde edinilmiştir.

İstanbul Müftülüğü. (2010a). Çağımızın problemleri. http://istanbulmuftulugu.gov.tr/hutbeler adresinden 20.06.2011 tarihinde edinilmiştir.

İstanbul Müftülüğü. (2010b). Kent ahlakı. http://istanbulmuftulugu.gov.tr/hutbeler adresinden 20.06.2011 tarihinde edinilmiştir. 
Kara, İ. (2008). Cumhuriyet Türkiyesi'nde bir mesela olarak İslam. İstanbul: Dergah Yayınları.

Keleş, R., Hamamcı, C. ve Çoban, A. (2009). Çevre politikası. Ankara: İmge Kitabevi.

Lock, G. (1996). Subject, interpellation and ideology. In A. Callari \& D. F. Ruccio (Eds.), Postmodern materialism and the future of Marxist theory (pp. 69-91). London: Wesleyan University Press.

Mardin, Ş. (2010). Din ve ideoloji. İstanbul: Illetişim Yayınları.

Muck, R. (2003). Marx@2000 (çev. Y. Yusufoğlu). İstanbul: Kitap Yayınevi.

Negri, A. (1996). Notes on the evolution of the thought of later Althusser (trans. O. Vasile). In A. Callari \& D. F. Ruccio (Eds.), Postmodern materialism and the future of Marxist theory (pp. 51-69). London: Wesleyan University Press.

Salleh, A. (1997). Ecofeminism as politics: Nature, Marx and the postmodern. New York: Zed Books.

Sancar, S. (2008). Ideolojinin serüveni, yanliş bilinç ve hegemonyadan söyleme. Ankara: İmge Kitabevi.

Suna, M. (1996). Günümüz cuma hutbelerinin toplumu eğitmedeki etkileri. Yayımlanmamış yüksek lisans tezi, Selçuk Üniversitesi, Sosyal Bilimler Enstitüsü, Konya.

Tura, S. M. (1990). Bir filozof olarak Althusser, Althusser'i okumak. Birikim, 20 (Aralık), 26-36.

Usta, E. Ş. (2005). Atatürk'ün hazırlattığı cuma hutbeleri. İstanbul: İleri Yayınları.

Vahid, A. (1928). Türkçe hutbeler. İstanbul: Amedi Matbaası.

Vincent, A. (2006). Modern politik ideolojiler (çev. A. Tüfekçi). İstanbul: Paradigma Yayıncılık. 